Article

\title{
The Effects of Lactose Induction on a Plasmid-Free E. coli T7 Expression System
}

\author{
Johanna Hausjell ${ }^{1,+}{ }^{,}$, Regina Kutscha ${ }^{1,+}$, Jeannine D. Gesson ${ }^{2}$, Daniela Reinisch ${ }^{2}$ and \\ Oliver Spadiut $1, * \mathbb{D}$ \\ 1 TU Wien, Institute of Chemical, Environmental and Bioscience Engineering, Research Division Biochemical \\ Engineering, 1060 Vienna, Austria; johanna.hausjell@tuwien.ac.at (J.H.); regina_phf1@yahoo.de (R.K.) \\ 2 Boehringer Ingelheim RCV GmbH \& Co KG, 1120 Vienna, Austria; \\ jeannine.gesson@boehringer-ingelheim.com (J.D.G.); daniela.reinisch@boehringer-ingelheim.com (D.R.) \\ * Correspondence: oliver.spadiut@tuwien.ac.at; Tel.: +43-1-58801-166473; Fax: +43-1-58801-166980 \\ + These authors contributed equally to this work.
}

Received: 5 November 2019; Accepted: 3 January 2020; Published: 6 January 2020

\begin{abstract}
Recombinant production of pharmaceutical proteins like antigen binding fragments (Fabs) in the commonly-used production host Escherichia coli presents several challenges. The predominantly-used plasmid-based expression systems exhibit the drawback of either excessive plasmid amplification or plasmid loss over prolonged cultivations. To improve production, efforts are made to establish plasmid-free expression, ensuring more stable process conditions. Another strategy to stabilize production processes is lactose induction, leading to increased soluble product formation and cell fitness, as shown in several studies performed with plasmid-based expression systems. Within this study we wanted to investigate lactose induction for a strain with a genome-integrated gene of interest for the first time. We found unusually high specific lactose uptake rates, which we could attribute to the low levels of lac-repressor protein that is usually encoded not only on the genome but additionally on pET plasmids. We further show that these unusually high lactose uptake rates are toxic to the cells, leading to increased cell leakiness and lysis. Finally, we demonstrate that in contrast to plasmid-based T7 expression systems, IPTG induction is beneficial for genome-integrated T7 expression systems concerning cell fitness and productivity.
\end{abstract}

Keywords: E. coli; T7 expression system; plasmid-free expression; lactose induction; antigen binding fragment (Fab); lac-repressor (LacI)

\section{Introduction}

E. coli is one of the most widely used hosts for recombinant protein production to date. Genetic manipulation is easy and versatile, there are numerous strains and plasmids available, and the cells can be cultivated fast, in cheap media, to high cell densities [1-5].

Conventionally, plasmids are used for recombinant protein production in E. coli, including the most frequently employed pET vectors, commercially established by Novagen ${ }^{\mathrm{TM}}$. On pET plasmids, the gene of interest (GOI) is encoded under control of the T7 promoter, which is recognized by T7 RNA polymerase. Compatible strains like E. coli BL21 (DE3), have the $\lambda$ DE3 region integrated into the genome, where transcription of T7 RNA polymerase is controlled by the lacUV5 promoter. Therefore, transcription and translation of the GOI depends upon transcription and translation of the T7 RNA polymerase from the lacUV5 promoter. Before induction, transcription of the T7 RNA polymerase and consequently the GOI are inhibited by the lac-repressor (LacI) which binds in a tetrameric structure to the respective operator sites [6]. Lac operator sites are located in (I) the native E. coli lac promoter (II) the lacUV5 promoter, which regulates transcription of the T7 RNA polymerase and (III) in the lac operator 
regions included downstream of the $\mathrm{T} 7$ promoter and upstream of the translation initiation sequence of the GOI for ensuring tighter transcription control [6]. A copy of lacI is present in the genomic DNA of the cell as well as on pET plasmids. During induction, the LacI-tetramer is bound by allolactose or one of its analogs, dissociates from the operator-sites and enables transcription and translation of the T7 RNA polymerase and thus in turn expression of the GOI from the T7 promoter [7-9].

Unfortunately, plasmid-based expression systems exhibit certain drawbacks. They either (I) tend to amplify the plasmid copy number in prolonged cultivations, or (II) plasmids are lost over time, propagating the segregation of a plasmid-free sub-population during induction. The latter has also been described in context with T7-pET systems, making establishment of stable production processes challenging [10,11].

One way to overcome these challenges is employment of plasmid-free expression systems, where the GOI is integrated directly into the host genome. A number of recombination methods have been developed for establishment of such systems and different suitable chromosomal integration sites in $E$. coli have been investigated [12,13]. Once the GOI is integrated into the genome, recombinant production is no longer subject to plasmid number variations, allowing, aside from stable processes, the establishment of a reference for the performance of plasmid-based systems as well. However, one of the major drawbacks of moving away from plasmid-based systems remains, leading to a slightly limited production capacity due to the lowered copy number of the GOI [1,14-16].

The gold standard for induction in T7 expression systems is IPTG, as it ensures stable and strong induction since it is not metabolized by the cells. This makes one point addition sufficient, easing handling of bioprocesses. Nevertheless, it has been reported that IPTG puts a high metabolic burden on the cells, decreases the amount of soluble recombinant protein, and exacerbates substrate toxicity [17-19]. One way to tackle these adverse effects is to use lactose as inducer, which has been shown to yield in similar if not higher product titers and to increase soluble product formation and cell fitness, enabling longer production times [19-22]. Additionally, lactose is cheap and non-toxic. Nevertheless, it has to be kept in mind that the disaccharide has to be supplied constantly, as it is rapidly metabolized by the cells.

Recent studies from our group showed that there is a correlation between the maximum specific lactose uptake rate $\left(\mathrm{q}_{\mathrm{s}, \text { lac,max }}\right)$ and the specific glucose uptake rate $\left(\mathrm{q}_{\mathrm{s}, \mathrm{glu}}\right)$ in E. coli BL21 (DE3) strains carrying pET plasmids. For several different $\mathrm{pET}$ plasmids for expression of various products, a mechanistic model for this correlation has been established, which can serve as a basis for steering product titers, product properties and/or product location [20,23,24].

Within this study we wanted to investigate the potential differences in the correlation between $\mathrm{q}_{\mathrm{s}, \text { glu }}$ and $\mathrm{q}_{\mathrm{s}, \text { lac,max }}$ for a strain where the GOI was not located on a pET plasmid but genome-integrated, knowledge which has not been generated to date. We wanted to shed light on the role of the plasmid and investigate if differences in the correlation were detectable when switching from plasmid-based to genome-integrated systems. As a model protein FabZ, an antigen binding fragment (Fab), was used which was translocated into the periplasm, as the oxidizing environment there allows necessary formation of disulfide bonds. As it is well known that periplasmic protein production can lead to cell leakiness and lysis [25], we further investigated if lactose induction had a positive effect in this regard. Finally, we compared induction by lactose to a standard IPTG-induced FabZ production process concerning productivity as well as physiology and viability.

\section{Materials and Methods}

\subsection{Strains}

In this study we used an E. coli BL21 (DE3) strain, which was provided by Boehringer Ingelheim RCV. The genes for the FabZ heavy chain and the FabZ light chain were encoded under the control of the T7 promoter and integrated into the genome at the attTN7 site by recombineering according to [26]. The homologous overhangs were each approximately $50 \mathrm{bp}$. Each gene was preceded by an 
ompA leader sequence (signal sequence for translocation into the periplasm) and a ribosomal binding site for efficient translation. A bicistronic mRNA was used, were the T7 promoter is followed by the open reading frame of the light chain including the ompA leader sequence and subsequently the open reading frame of the heavy chain also including the ompA leader sequence. Additionally, the strain carried a kanamycin-resistance. The ribosome binding site used was aagaaggaga. The ompA-leader sequence was MKKTAIAIAVALAGFATVAQA in terms of amino acids, the respective DNA-sequence was optimized together with the light and heavy chain of FabZ. Sequence details of the product FabZ are confidential. The heavy chain is $23.2 \mathrm{kDa}$ and has a pI between 9.05 and 9.06 (depending on the prediction tools used), the light chain is $23.1 \mathrm{kDa}$ and has a pI between 5.62 and 5.74 . The full construct is $46.3 \mathrm{kDa}$ and has a pI of 8.41. The overall integration cassette consisted of the T7-promoter, the ribosome binding site, ompA-light chain, ribosome binding site, ompA-heavy chain, the T7-terminator and a kanamycin resistance gene. Regarding the promoter, terminator, omp $A$ and the kanamycin resistance gene, standard sequences were used.

To study the influence of the lac-repressor (LacI), the strain was transformed with an empty pET-21 $\mathrm{d}(+)$ plasmid in the course of our investigation.

\subsection{Transformation with $p E T-21 d(+)$}

A heat-shock transformation of E. coli BL21(DE3) with pET-21 d (+) was performed. In order to produce chemically competent cells, the cells were grown in LB-medium at $37^{\circ} \mathrm{C}$ and $230 \mathrm{rpm}$ to an optical density of about 0.5 at $600 \mathrm{~nm}$. After centrifugation $\left(2500 \times g, 4{ }^{\circ} \mathrm{C}, 10 \mathrm{~min}\right)$ the supernatant was discarded and the cells were resuspended in $2 \mathrm{~mL}$ of ice-cold $30 \mathrm{mM} \mathrm{CaCl}_{2}$. Subsequently, the cells were spun down for $30 \mathrm{~s}$ and the pellet was gently resuspended in $0.5 \mathrm{~mL}$ of ice-cold $30 \mathrm{mM} \mathrm{CaCl}_{2}$.

$50 \mu \mathrm{L}$ of this cell-suspension were mixed with $3 \mu \mathrm{L}(442 \mathrm{ng})$ of plasmid DNA and incubated on ice for $30 \mathrm{~min}$. Then the mixture was incubated at $42{ }^{\circ} \mathrm{C}$ for $30 \mathrm{~s}$ and then on ice for $5 \mathrm{~min}$. Next, $950 \mu \mathrm{L}$ of SOC-medium $(0.5 \%$ yeast extract, $2 \%$ tryptone, $10 \mathrm{mM} \mathrm{NaCl}, 2.5 \mathrm{mM} \mathrm{KCl}, 10 \mathrm{mM} \mathrm{MgCl}, 10 \mathrm{mM}$ $\mathrm{MgSO}_{4}$, and $20 \mathrm{mM}$ glucose) were added, and the cells were regenerated at $30^{\circ} \mathrm{C}$ and $180 \mathrm{rpm}$ for $1 \mathrm{~h}$.

For selection, the cells were grown on LB-agar plates containing $50 \mu \mathrm{g} / \mathrm{mL}$ kanamycin and $100 \mathrm{\mu g} / \mathrm{mL}$ ampicillin at $30^{\circ} \mathrm{C}$ for $72 \mathrm{~h}$. Successful transformation of the cells with the plasmid was confirmed by isolation and commercial sequencing (Microsynth Austria AG, Vienna, Austria).

\subsection{Bioreactor Cultivations}

Cultivations were carried out once in the controlled environment of a bioreactor, closing C-balances were used as a control for calculations. Measurements and analyses of samples were carried out in triplicates. All bioreactor cultivations included a batch phase, an uninduced fed-batch phase to a dry cell weight concentration of $30 \mathrm{~g} / \mathrm{L}$, and an induction phase of $6 \mathrm{~h}$.

Cultivations were performed in DASbox ${ }^{\circledR}$ Mini Bioreactors (Eppendorf, Hamburg, Germany) with $250 \mathrm{~mL}$ working volume. The $\mathrm{pH}$ was measured via $\mathrm{pH}$-Sensor EasyFerm Plus (Hamilton, Reno, NV, USA) probes, dissolved oxygen with Visiferm DO 120 electrodes (Hamilton, Reno, NV, USA), and $\mathrm{CO}_{2}$ and $\mathrm{O}_{2}$ in the offgas via a DASGIP ${ }^{\circledR}$ GA gas analyzer (Eppendorf, Hamburg, Germany). For aeration a mixture of pressurized air and pure oxygen was provided at $18 \mathrm{~L} / \mathrm{h}$. The stirring speed was kept at $2000 \mathrm{rpm}$. The dissolved oxygen saturation was held above $30 \%$ by adding more pure oxygen if required. The feed-flowrates were regulated via a DASbox ${ }^{\circledR}$ MP8 Multi Pump Module, the pH was kept at 6.8 during batch and fed-batch phase, and was adjusted to 7.1 during the induction phase. The temperature was controlled at $37^{\circ} \mathrm{C}$ during the growth phases and subsequently lowered to $32{ }^{\circ} \mathrm{C}$ for the induction phase. The process parameters were recorded and controlled by DASware ${ }^{\circledR}$ control.

Five hundred milliliters of DeLisa pre-culture medium [27], containing $30 \mathrm{mg} / \mathrm{L}$ kanamycin, were inoculated aseptically with one frozen stock of cells $\left(-80^{\circ} \mathrm{C} ; 1.5 \mathrm{~mL}\right)$ and incubated overnight (approximately $\sim 17 \mathrm{~h}$ ) in $2500 \mathrm{~mL}$ high-yield shake flasks at $37^{\circ} \mathrm{C}$ and $200 \mathrm{rpm}$. The DeLisa batch medium was inoculated with $10 \%$ of the starting volume. After the sugar was depleted, indicated by a drop in the $\mathrm{CO}_{2}$ signal, the biomass concentration was further increased (to approximately $30 \mathrm{~g} / \mathrm{L}$ ) 
by carrying out a fed-batch phase with a glucose feed of $400 \mathrm{~g} / \mathrm{L}$. The production of FabZ was either induced with $1.25 \mathrm{mM} \mathrm{IPTG}$, as used the industrially developed process, following an induction phase with an average $\mathrm{q}_{\mathrm{s}, \mathrm{glu}}$ of $0.13 \mathrm{~g} / \mathrm{g} / \mathrm{h}$, or, for lactose induction, two feeds including a $400 \mathrm{~g} / \mathrm{L}$ glucose feed as well as a $200 \mathrm{~g} / \mathrm{L}$ lactose feed were utilized to achieve the desired specific sugar uptake rates.

\subsection{Feed Control Strategy}

The amount of feed added to the reactors for exponential fed-batch phases was calculated by the control software using a simple feed-forward exponential feeding strategy, according to the following equation:

$$
\text { Feed setpoint }\left[\frac{m L}{h}\right]=\mathrm{q}_{\mathrm{s}} * V * c_{x} * e^{(u * t)} * \frac{1000}{c_{s}} \text {. }
$$

$\mu$ specific growth rate on glucose/lactose $\left[\mathrm{h}^{-1}\right]$

$\mathrm{q}_{\mathrm{s}}$ specific glucose/lactose uptake rate $\left[\mathrm{g}_{\mathrm{x}} / \mathrm{g}_{\mathrm{s}} / \mathrm{h}\right]$

$V$ reactor volume [L]

$c_{x}$ biomass concentration $\left[g_{x} / \mathrm{L}\right]$

$t$ time [h]

$c_{s}$ concentration of the feed $\left[\mathrm{g}_{\mathrm{s}} / \mathrm{L}\right]$

The growth rate was calculated from the specific sugar uptake rates and yields on the respective sugars.

\subsection{Sampling}

Samples were taken at the start of the batch phase, at the start of the fed-batch phase, at the beginning of the induction, and in different intervals during induction. For cultivations needed for the correlation between $\mathrm{q}_{\mathrm{s}, \mathrm{glu}}$ and $\mathrm{q}_{\mathrm{s}, \text { lac,max }}$ the sampling interval was one hour, for further experiments concerning tunability and the influence of LacI the sampling interval was widened to $6 \mathrm{~h}$. For every sample the optical densities at $600 \mathrm{~nm}\left(\mathrm{OD}_{600}\right)$ and at $550 \mathrm{~nm}\left(\mathrm{OD}_{550}\right)$ were determined spectroscopically using a Genesys 20 photometer (Thermo Scientific, Waltham, MA, USA), using appropriate dilutions to stay in the linear range $\left(\mathrm{OD}_{600} 0.2-0.8\right)$.

Biomass aliquots of each sample were generated by pipetting an amount of cell broth calculated via Equation (2),

$$
\text { sample volume }[m L]=\frac{10}{O D_{550}},
$$

into $500 \mu \mathrm{L}$ of $0.9 \% \mathrm{NaCl}$ solution.

These aliquots were then centrifuged at $20,000 \times g$ at $4{ }^{\circ} \mathrm{C}$ for $10 \mathrm{~min}$ in a Sigma $3-18 \mathrm{~K}$ centrifuge. The supernatant was discarded and the samples were frozen at $-20{ }^{\circ} \mathrm{C}$ for product analytics.

Dry cell weight was determined gravimetrically by pipetting $1 \mathrm{~mL}$ of sample into pre-weighed 2 $\mathrm{mL}$ Eppendorf tubes, centrifuging at $20,000 \times \mathrm{g}$ at $4{ }^{\circ} \mathrm{C}$ for $10 \mathrm{~min}$ using a Sigma $3-18 \mathrm{~K}$ centrifuge (Sigma Laborzentrifugen $\mathrm{GmbH}$, Osterode am Harz, Germany), resuspending the pellet in $1 \mathrm{~mL}$ of $0.9 \% \mathrm{NaCl}$, centrifuging again at the same conditions and drying the pellets at $110{ }^{\circ} \mathrm{C}$ for $72 \mathrm{~h}$. Subsequently, the pellets were weighed.

Additionally, at the end of the cultivation, several $10 \mathrm{~mL}$ samples of culture broth were taken, centrifuged at $5000 \times g$ for $30 \mathrm{~min}$ at $4{ }^{\circ} \mathrm{C}$ and the pellet was frozen at $-20^{\circ} \mathrm{C}$ for later homogenization.

The concentrations of glucose, lactose, galactose, and acetate were determined via HPLC in the cell-free supernatant (Thermo Fisher Scientific, Waltham, MA USA) with an Aminex HPX-87H Column (Bio-Rad, Hercules, CA, USA) using $4 \mathrm{mM} \mathrm{H}_{2} \mathrm{SO}_{4}$ for isocratic separation and a RefractoMax520 refractive index detector (DataApex, Petrzilkova, Prague, Czech Republic). The flowrate was set to $0.6 \mathrm{~mL} / \mathrm{min}$ and the method lasted for $30 \mathrm{~min}$. All analyses were performed in triplicates. 


\subsection{Product Analytics}

Product analytics of soluble product in the cells and in the cell-free supernatant were carried out according to procedures previously described in literature [28].

\subsection{Leakiness (Alkaline Phosphatase Assay)}

Within our study the term "leakiness" refers to cells where alkaline phosphatase and FabZ can be detected in the culture supernatant, indicating a permeable outer membrane. This includes cells, which are lysed and have an open outer membrane for this reason. However, we additionally determined DNA contents in the culture supernatant, which rise upon cell lysis. To determine cell leakiness, an alkaline phosphatase assay was performed with the cell-free supernatants according to literature [25]. For comparability reasons between different cultivations, the slopes of the measurements were divided by the biomass concentration.

Additionally, cells were homogenized by resuspending the pellets from the $10 \mathrm{~mL}$ samples in buffer $\mathrm{A}\left(20 \mathrm{mM} \mathrm{NaH} \mathrm{PO}_{4} \cdot 2 \mathrm{H}_{2} \mathrm{O}, 100 \mathrm{mM} \mathrm{NaCl}, \mathrm{pH}\right.$ 7) and running 10 passages at approximately 1000 bar in a Panda Plus Homogenizer (GEA Niro Soavi, Parma, Italy). After the subsequent centrifugation at $15,000 \times g$ and $4{ }^{\circ} \mathrm{C}$ for $20 \mathrm{~min}$, alkaline phosphatase activity was measured in the supernatant. The slopes of these measurements were again normalized by biomass used for homogenization. The resulting values were defined as $100 \%$ leakiness for the different cultivations.

\subsection{Lysis (Picogreen Assay)}

To estimate the amount of lysed cells, Quant-iT ${ }^{\mathrm{TM}}$ PicoGreen $^{\circledR}$ dsDNA assays (Invitrogen $^{\mathrm{TM}}$, Thermo Fisher Scientific, Waltham, MA USA) were performed using a Quant-iT ${ }^{\mathrm{TM}}$ PicoGreen $^{\mathrm{TM}}$ dsDNA Assay Kit. After preparing a working solution (200-fold dilution of the concentrated DMSO solution of Quant-iT ${ }^{\text {TM }}$ PicoGreen ${ }^{\circledR}$ reagent in TE-buffer $(10 \mathrm{mM}$ Tris-HCl, 1 mM EDTA, pH 7.5)), $100 \mu \mathrm{L}$ thereof were mixed with $100 \mu \mathrm{L}$ of 100-fold diluted cell-free supernatant and incubated in the dark at room temperature for $5 \mathrm{~min}$. Fluorescence was measured by exciting at $480 \mathrm{~nm}$ and measuring the emission at $520 \mathrm{~nm}$ using an Infinite 200 Pro plate reader (Tecan, Zürich, Switzerland). The calibration was done with the lambda DNA standard provided in the assay kit in a range of $1 \mathrm{ng} / \mathrm{mL}$ to $1 \mu \mathrm{g} / \mathrm{mL}$. In order to compare the results of different cultivations at different times, the resulting DNA-concentrations were normalized by biomass.

\section{Results and Discussion}

\subsection{Correlation between $q_{s, g l u}$ and $q_{s, l a c, \max }$}

We wanted to shed light on the mechanistic correlation between the specific glucose uptake rate $\left(\mathrm{q}_{\mathrm{s}, \mathrm{glu}}\right)$ and the maximum specific lactose uptake rate $\left(\mathrm{q}_{\mathrm{s}, \text { lac,max }}\right)$ for a genome-integrated FabZ E. coli BL21 (DE3) strain (hereafter referred to as GI-strain). Previously, this correlation had only been recorded for plasmid-based T7 expression systems, where results showed that the correlation differed, dependent on the pET-plasmid and the expressed protein (Figure 1a) [23].

To determine the correlation between $\mathrm{q}_{\mathrm{s}, \mathrm{glu}}$ and $\mathrm{q}_{\mathrm{s}, \mathrm{lac} \text {, max }}$ for the GI strain, bioreactor cultivations at different $\mathrm{q}_{\mathrm{s}, \mathrm{glu}}$ set-points were carried out while supplying lactose in excess. The excess lactose supply was confirmed by HPLC-measurements, where lactose was detected in the supernatant of the culture broth at quantities greater than $0.5 \mathrm{~g} / \mathrm{L}$ at all times. The actual specific lactose uptake rate was determined after an adaption phase ranging from $2 \mathrm{~h}$ to $5 \mathrm{~h}$, which depended on the specific glucose uptake rate. The end of the adaption phase was indicated by a subsequently constant $\mathrm{q}_{\mathrm{s}, \mathrm{lac} \text {, max }}$. 

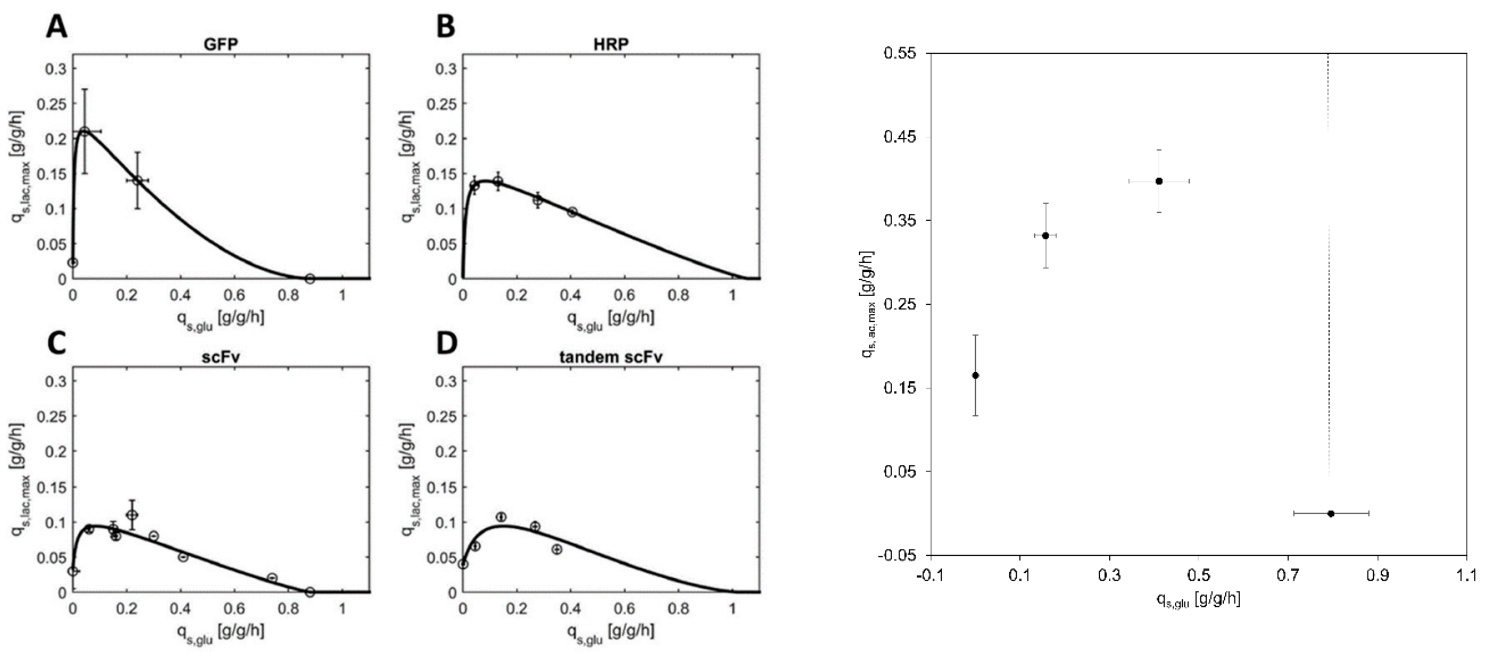

(a)

(b)

Figure 1. $\mathrm{q}_{\mathrm{s}, \mathrm{glu}} / \mathrm{q}_{\mathrm{s}, \text { lac,max }}$-correlations (a) $\mathrm{q}_{\mathrm{s}, \mathrm{glu}} / \mathrm{q}_{\mathrm{s}, \text { lac,max }}$-correlation for recombinant $\mathrm{pET}$-based E. coli BL21 (DE3) strains producing either (A) GFP, (B) HRP, (C) the scFv or (D) the tandem scFv. Data-points were obtained from batch and fed-batch cultivations with constant $\mathrm{q}_{\mathrm{s}, \mathrm{glu}}$ and excess lactose ("static experiments") and subsequently fitted to the mechanistic model (Equation (1)) reprinted from [23] as a comparison to previously recorded correlations between $\mathrm{q}_{\mathrm{s}, \mathrm{glu}}$ and $\mathrm{q}_{\mathrm{s}, \mathrm{lac} \text {, max }}$ for plasmid-containing BL21 (DE3) strains. (b) $\mathrm{q}_{\mathrm{s}, \mathrm{lac} \text {,max }}$ as a function of $\mathrm{q}_{\mathrm{s} \text {, glu }}$ for the GI strain; the data-points were gained from the different batch and fed-batch cultivations: Point $1\left(\mathrm{q}_{\mathrm{s}, \mathrm{lac}, \max } 0.17 \pm 0.05 \mathrm{~g} / \mathrm{g} / \mathrm{h}\right.$ at $\mathrm{q}_{\mathrm{s}, \mathrm{glu}} 0 \mathrm{~g} / \mathrm{g} / \mathrm{h}$ ) is derived from a fed-batch only on lactose, the two middle points $\left(\mathrm{q}_{\mathrm{s}, \mathrm{lac}, \max } 0.33 \pm 0.05 \mathrm{~g} / \mathrm{g} / \mathrm{h}\right.$ at $\mathrm{q}_{\mathrm{s}, \mathrm{glu}}$ $0.19 \pm 0.04 \mathrm{~g} / \mathrm{g} / \mathrm{h} ; \mathrm{q}_{\mathrm{s}, l a c, \max } 0.40 \pm 0.04 \mathrm{~g} / \mathrm{g} / \mathrm{h}$ at $\mathrm{q}_{\mathrm{s}, \mathrm{glu}} 0.41 \pm 0.07 \mathrm{~g} / \mathrm{g} / \mathrm{h}$ ) were calculated from fed-batch cultivations where limiting amounts of glucose were fed and lactose was provided in excess, and point 4 (on the right) indicates the value of the maximum specific glucose uptake rate. Above this point, also indicated by a dotted line, glucose would accumulate and therefore no lactose uptake would occur due to the well-known phenomenon of diauxic growth and carbon catabolite repression whenever glucose and lactose are present in excess e.g., [29-31]. The error bars indicate the standard deviation of $\mathrm{q}_{\mathrm{s}, \mathrm{glu}}$ and $\mathrm{q}_{\mathrm{s}, \text { lac,max }}$ during the cultivations.

Based on previously recorded $\mathrm{q}_{\mathrm{s}, \mathrm{glu}}-\mathrm{q}_{\mathrm{s}, \mathrm{lac} \text {,max }}$ correlations for plasmid-carrying E. coli BL21 (DE3) [23], we expected very little lactose uptake ( $\mathrm{q}_{\mathrm{s}, \mathrm{lac}, \max }$ below $\left.0.05 \mathrm{~g} / \mathrm{g} / \mathrm{h}\right)$ in the complete absence of glucose. Additionally, we expected the highest $\mathrm{q}_{\mathrm{s}, \mathrm{lac} \text {, max }}$ at a specific glucose uptake rate of about 0.1 to $0.2 \mathrm{~g} / \mathrm{g} / \mathrm{h}$. At those values usually $\mathrm{q}_{\mathrm{s}, \mathrm{lac} \text { max }}$ of 0.1 to $0.2 \mathrm{~g} / \mathrm{g} / \mathrm{h}$ were reached (Figure $1 \mathrm{a}$ ).

However, as shown in Figure 1b, the correlation for the GI strain differed strongly. In contrast to plasmid-based systems, where we detected almost no capability for lactose uptake if glucose was absent $\left(\mathrm{q}_{\mathrm{s}, \mathrm{lac} \text { max }}<0.05 \mathrm{~g} / \mathrm{g} / \mathrm{h}\right)$, we noticed considerable cell growth (Supplementary Table S1) and lactose uptake in the GI strain without supplementation of glucose $\left(\mathrm{q}_{\mathrm{s}, \mathrm{lac} \text {, max }}=0.17 \mathrm{~g} / \mathrm{g} / \mathrm{h}\right)$.

Aside from this astonishingly high lactose uptake in the absence of glucose, we also observed differences in the maximum of the $\mathrm{q}_{\mathrm{s}, \mathrm{glu}}-\mathrm{q}_{\mathrm{s}, \text { lac, max }}$ correlation. With $0.40 \mathrm{~g} / \mathrm{g} / \mathrm{h}$, the highest $\mathrm{q}_{\mathrm{s}, \text { lac,max }}$ of

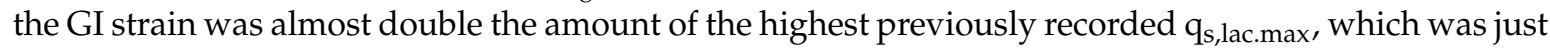
above $0.2 \mathrm{~g} / \mathrm{g} / \mathrm{h}$ for an E. coli BL21 (DE3) strain, expressing green fluorescent protein from a pET-21 a (+) plasmid. Further, the highest $\mathrm{q}_{\mathrm{s}, \mathrm{lac} \text { max }}$ of the GI strain occurred at clearly elevated $\mathrm{q}_{\mathrm{s}, \mathrm{glu}}$-values. While in plasmid-based systems the highest $\mathrm{q}_{\mathrm{s}, l a c, m a x}$ correlates to $\mathrm{q}_{\mathrm{s}, \mathrm{glu}}$ values between 0.1 and $0.2 \mathrm{~g} / \mathrm{g} / \mathrm{h}$, the highest $\mathrm{q}_{\mathrm{s}, \mathrm{lac} \text {,max }}$ recorded for the GI strain is found at a $\mathrm{q}_{\mathrm{s}, \mathrm{glu}}$ of $0.41 \mathrm{~g} / \mathrm{g} / \mathrm{h}$. Unfortunately, we were not able to determine $\mathrm{q}_{\mathrm{s}, \mathrm{lac} \text {, max }}$-values at higher $\mathrm{q}_{\mathrm{s}, \mathrm{glu}}$, since the cells tended to get leaky and lyse very quickly (in a matter of about $6 \mathrm{~h}$; Figure 2a) if exposed to excess lactose for a prolonged time. Consequently, the cells had barely any time to fully adapt to lactose before lysing and there was no possibility to analyze the correlation at higher $\mathrm{q}_{\mathrm{s}, \mathrm{glu}}$ points, rendering a mechanistic modelling, as it has been done before [23], impossible. 


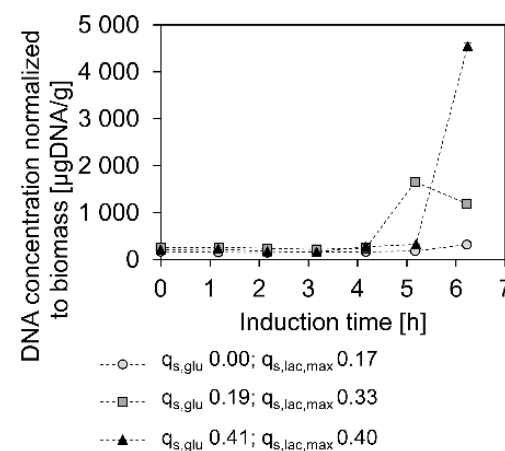

(a)

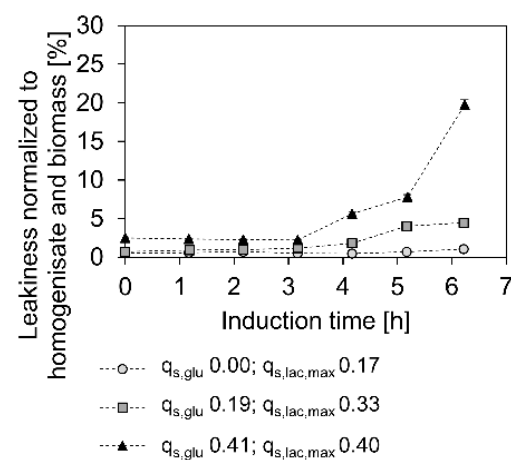

(b)

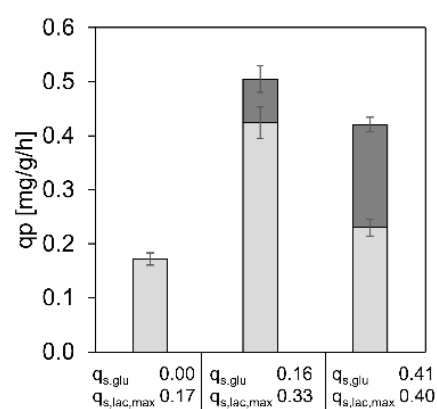

(c)

Figure 2. Leakiness, lysis and productivity at different $\mathrm{q}_{\mathrm{s}, \mathrm{glu}} / \mathrm{q}_{\mathrm{s}, \mathrm{lac}, \max }(\mathbf{a})$ Lysis normalized to biomass at the different $\mathrm{q}_{\mathrm{s}, \text { glu }}$ and correlating $\mathrm{q}_{\mathrm{s}, \mathrm{lac} \text {,max }}$ values: black triangles indicate values for $\mathrm{q}_{\mathrm{s}, \mathrm{glu}}=0.41 \mathrm{~g} / \mathrm{g} / \mathrm{h}$ $\mathrm{q}_{\mathrm{s}, \text { lac,max }}=0.40 \mathrm{~g} / \mathrm{g} / \mathrm{h}$, grey squares represent $\mathrm{q}_{\mathrm{s}, \mathrm{glu}}=0.19 \mathrm{~g} / \mathrm{g} / \mathrm{h} \mathrm{q} \mathrm{q}_{\mathrm{s}, \mathrm{lac} \text { max }}=0.33 \mathrm{~g} / \mathrm{g} / \mathrm{h}$, light grey circles are values obtained from the lactose batch experiment. (b) Leakiness normalized to biomass: Black triangles indicate values for $\mathrm{q}_{\mathrm{s}, \mathrm{glu}}=0.41 \mathrm{~g} / \mathrm{g} / \mathrm{h} \mathrm{q}_{\mathrm{s}, \mathrm{lac}, \max }=0.40 \mathrm{~g} / \mathrm{g} / \mathrm{h}$, grey squares represent $\mathrm{q}_{\mathrm{s}, \mathrm{glu}}=0.19 \mathrm{~g} / \mathrm{g} / \mathrm{h}$ $\mathrm{q}_{\mathrm{s}, \text { lac, } \max }=0.33 \mathrm{~g} / \mathrm{g} / \mathrm{h}$, light grey circles are values obtained from the lactose batch experiment. (c) specific overall, intracellular (light grey), and extracellular (dark grey) product formation rates for the $\mathrm{q}_{\mathrm{s}, \mathrm{glu}}$ and correlating $\mathrm{q}_{\mathrm{s}, \mathrm{lac} \text {, max }}$ values.

Nevertheless, we investigated productivity at the different points along the $\mathrm{q}_{\mathrm{s}, \mathrm{lac} \text {, } \max }-\mathrm{q}_{\mathrm{s}, \mathrm{glu}}$ correlation curve. As shown in Figure 2c, the highest overall specific soluble product formation rate $\left(\mathrm{q}_{\mathrm{p}}\right.$ ) was detected at a medium $\mathrm{q}_{\mathrm{s}, \mathrm{glu}}$ of $0.19 \mathrm{~g} / \mathrm{g} / \mathrm{h}$ and a $\mathrm{q}_{\mathrm{s}, \mathrm{lac} \text { max }}$ of $0.33 \mathrm{~g} / \mathrm{g} / \mathrm{h}$. The cultivation at a $\mathrm{q}_{\mathrm{s}, \mathrm{glu}}$ of $0.41 \mathrm{~g} / \mathrm{g} / \mathrm{h}$ and a $\mathrm{q}_{\mathrm{s}, l a c, m a x}$ of $0.40 \mathrm{~g} / \mathrm{g} / \mathrm{h}$ yielded less FabZ per biomass and hour and the lactose batch cultivation only exhibited a $q_{p}$ below $0.2 \mathrm{mg} / \mathrm{g} / \mathrm{h}$. The overall trend, that $q_{p}$ is lower when little glucose is taken up but also when $\mathrm{q}_{\mathrm{s}, \mathrm{glu}}$ is high, is the same, as previously found for plasmid-based systems [24], although it has to be kept in mind, that only soluble product was investigated in this study.

Interestingly, the $\mathrm{q}_{\mathrm{p}}$ loss due to extracellular product clearly increased with higher specific lactose and glucose uptake rates. This most likely results from cell leakiness and lysis, as both seem to increase similarly at higher sugar uptake rates (Figure 2a,b). We hypothesized that at high specific lactose uptake rates the so-called lactose killing was triggered [32]. This phenomenon describes the death of E. coli grown on excess lactose and has been attributed to the transport of lactose through the cell membrane, influencing the proton motif force and leading to cell death [33]. In our case, the high specific glucose uptake rates and product formation in the periplasm might have additionally promoted cell lysis.

Summing up, we found similar trends for the productivity of the GI strain and plasmid-based expression systems along the $\mathrm{q}_{\mathrm{s}, \mathrm{lac} \text { max }}-\mathrm{q}_{\mathrm{s}, \mathrm{glu}}$ correlation curve, however, the curve of the GI strain itself was clearly higher and its maximum was shifted to the right. Previous cultivations for the plasmid based expression systems were carried out at $30^{\circ} \mathrm{C}$, however, we chose $32{ }^{\circ} \mathrm{C}$ for the induction of FabZ expression, as this was determined as optimal induction temperature for this protein. Although sugar uptake rates and growth rates rise with higher temperatures, we found it rather unlikely that rising the temperature by $2{ }^{\circ} \mathrm{C}$ was the cause for almost doubling the lactose uptake rates.

Instead, we hypothesized that the reason for this strong divergence could originate from the plasmids. All employed pET plasmids from our previous studies $[20,23,24,34]$ were high copy number plasmids, which also carried a lacI gene, thereby introducing much more repressor protein into the cells. The GI strain however, only expressed LacI from the copies in the genome [35]. Consequently, in the GI strain, less LacI would bind to the lac promoter and expression of lactose permease was elevated, allowing higher specific lactose uptake rates. 


\subsection{The Influence of LacI}

To test our hypothesis that the GI strain exhibited higher $\mathrm{q}_{\mathrm{s}, \text { lac,max }}$ values compared to plasmid-based systems, as a result of less lacI copies, an empty pET-21 d (+) plasmid was introduced into the GI strain. The high copy number plasmid carried an additional lacI gene. The transformed cells were cultivated in a bioreactor under the same conditions as before with an excess of lactose, at a $\mathrm{q}_{\mathrm{s}, \mathrm{glu}}$ comparable to $0.19 \mathrm{~g} / \mathrm{g} / \mathrm{h}$. Specific sugar uptake rates, productivity, and leakiness/lysis were evaluated for the plasmid containing GI strain and compared to previous results of the GI strain without plasmid (Figure 3).

\begin{tabular}{lll}
\hline & without plasmid & with plasmid \\
\hline$\mu\left[\mathrm{h}^{-1}\right]$ & $0.22 \pm 0.05$ & $0.13 \pm 0.01$ \\
$\mathrm{q}_{\mathrm{s}, \mathrm{glu}}[\mathrm{g} / \mathrm{g} / \mathrm{h}]$ & $0.19 \pm 0.04$ & $0.22 \pm 0.02$ \\
$\mathrm{q}_{\mathrm{s}, \mathrm{ac}, \max }[\mathrm{g} / \mathrm{g} / \mathrm{h}]$ & $0.33 \pm 0.04$ & $0.16 \pm 0.01$ \\
$\begin{array}{l}\text { DNA concentration } \\
\text { normalized to biomass } \\
\text { after 6 h of induction }\end{array}$ & $1190 \pm 7$ & $175 \pm 2$ \\
$\begin{array}{l}{[\mu \mathrm{g} / \mathrm{g}]} \\
\begin{array}{l}\text { Leakiness normalized } \\
\text { to homogenate and } \\
\text { biomass after 6 h of } \\
\text { induction [\%] }\end{array}\end{array}$ & \\
\hline
\end{tabular}

(a)

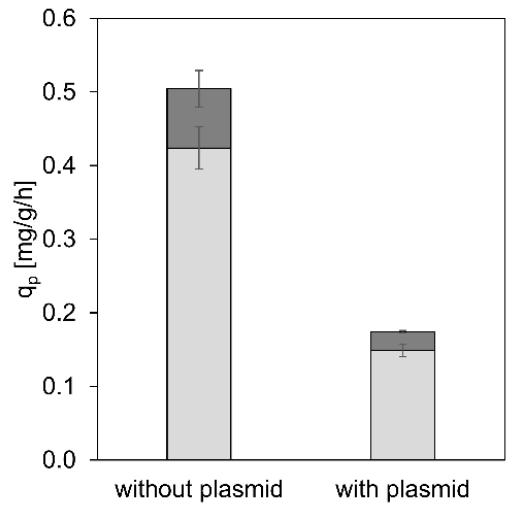

(b)

Figure 3. Physiology, leakiness, lysis and productivity for the GI-strain with and without an additional pET plasmid. (a) Comparison of physiological data as well as leakiness and lysis of a cultivation of the GI strain without plasmid and the GI strain containing the empty pET-21 d (+) plasmid; (b) Specific overall, intracellular (light grey), and extracellular (dark grey) product formation rates compared between the cultivations with and without plasmid.

At a comparable $\mathrm{q}_{\mathrm{s}, \mathrm{glu}}$, the plasmid-containing strain exhibited only a $\mathrm{q}_{\mathrm{s}, \mathrm{lac} \text {, max }}$ of $0.16 \mathrm{~g} / \mathrm{g} / \mathrm{h}$, approximately half of that of the GI strain without the plasmid and in the range of previously recorded $\mathrm{q}_{\mathrm{s}, \text { lac, max }}$ values, which were found between 0.1 and $0.2 \mathrm{~g} / \mathrm{g} / \mathrm{h}$. This confirmed our hypothesis that the shift in the $\mathrm{q}_{\mathrm{s}, \mathrm{lac} \text {, max }}-\mathrm{q}_{\mathrm{s}, \mathrm{glu}}$ correlation of the GI strain was a result of the reduced number of lacI copies.

In accordance with sugar uptake rates, productivity and cell lysis differed for the plasmid containing GI strain as well. Productivity was clearly reduced as a result of less T7 RNA polymerase expression from the lacUV5 promoter and cell lysis and leakiness were decreased as well, which we hypothesized could either be an effect of the lower specific lactose uptake rate or the lower amount of product in the periplasm of the cells.

\subsection{Toxicity of High Lactose Uptake Rates}

As including a pET-21 d (+) plasmid containing a lacI copy in the GI strain led to less cell lysis and leakiness, we were interested if the reason for this was the reduced productivity, putting less stress on the cells or the lower specific lactose uptake rate. For closer investigation we decided to perform two cultivations at the same $\mathrm{q}_{\mathrm{s}, \mathrm{glu}}(0.14 \mathrm{~g} / \mathrm{g} / \mathrm{h})$ and at $100 \% \mathrm{q}_{\mathrm{s}, \mathrm{lac} \text {,max }}$ as well as approximately $60 \%$ of $\mathrm{q}_{\mathrm{s}, \mathrm{lac}, \max }$, as it has previously been shown that reducing $\mathrm{q}_{\mathrm{s}, \text { lac, max }}$ to $57 \%$ still leads to comparable specific product formation rates (95.5\% target protein) [20]. Results are shown in Figure 4.

As shown in Figure $4 b$, indeed a similar overall $q_{p}$ was reached in both cultivations $\left(88 \%\right.$ of the $q_{p}$ at $100 \% \mathrm{q}_{\mathrm{s}, \mathrm{lac} \text {, max }}$ was still reached at $60 \% \mathrm{q}_{\mathrm{s}, \text { lac,max }}$. However, in the cultivation at $60 \% \mathrm{q}_{\mathrm{s}, \text { lac,max }}$ more product is found intracellularly and less in the cultivation supernatant. This is a result of less cell lysis and leakiness as shown in Figure 4a, indicating that not recombinant protein production but the high lactose uptake rates are toxic for the cells. 


\begin{tabular}{|c|c|c|}
\hline & $100 \% \mathrm{q}_{\mathrm{s}, \mathrm{lac}, \max }$ & $60 \% q_{\mathrm{s}, \mathrm{lac} \text { max }}$ \\
\hline$\mu\left[\mathrm{h}^{-1}\right]$ & $0.12 \pm 0.03$ & $0.12 \pm 0.01$ \\
\hline $\mathrm{q}_{\mathrm{s}, \mathrm{glu}}[\mathrm{g} / \mathrm{g} / \mathrm{h}]$ & $0.13 \pm 0.02$ & $0.15 \pm 0.01$ \\
\hline $\mathrm{q}_{\mathrm{s}, \mathrm{lac}, \max }[\mathrm{g} / \mathrm{g} / \mathrm{h}]$ & $0.33 \pm 0.02$ & $0.20 \pm 0.01$ \\
\hline $\begin{array}{l}\text { DNA concentration } \\
\text { normalized to biomass } \\
\text { after } 6 \text { h of induction } \\
{[\mu \mathrm{g} / \mathrm{g}]}\end{array}$ & $1310 \pm 49$ & $262 \pm 8$ \\
\hline $\begin{array}{l}\text { Leakiness normalized } \\
\text { to homogenate and } \\
\text { biomass after } 6 \mathrm{~h} \text { of } \\
\text { induction [\%] }\end{array}$ & $15.5 \pm 0.5$ & $4.4 \pm 0.1$ \\
\hline
\end{tabular}

(a)

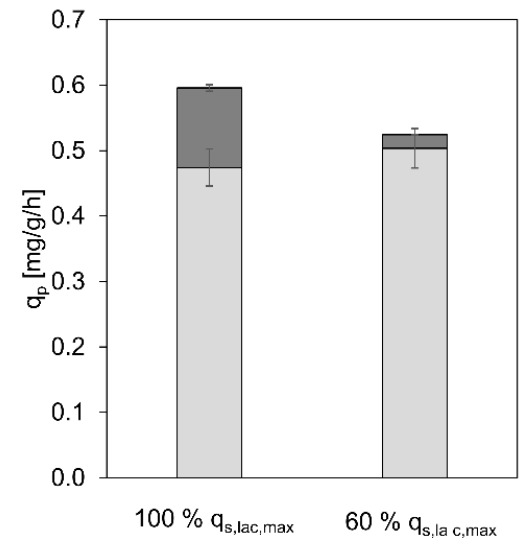

(b)

Figure 4. Physiology, leakiness, lysis and productivity at $100 \%$ and $60 \% \mathrm{q}_{\mathrm{s}, \mathrm{lac} \text {,max }}$ (a) Comparison of physiological data as well as leakiness and lysis of a cultivation at a $\mathrm{q}_{\mathrm{s}, \mathrm{glu}} 0.14 \mathrm{~g} / \mathrm{g} / \mathrm{h}$ and different $\mathrm{q}_{\mathrm{s}, \mathrm{lac}}$ $\left(100 \% \mathrm{q}_{\mathrm{s}, \mathrm{lac}, \max }\right.$ and $60 \% \mathrm{q}_{\mathrm{s}, \text { lac,max }}$ ); (b) specific overall, intracellular (light grey), and extracellular (dark grey) product formation rates of cultivations at $100 \% \mathrm{q}_{\mathrm{s}, \text { lac, } \max }$ and $60 \% \mathrm{q}_{\mathrm{s}, \mathrm{lac} \text {, max }}$.

\subsection{Comparison between Lactose Induction and IPTG Induction}

For plasmid-based systems it has been reported that lactose induction provided the advantages of increased soluble product formation and cell fitness [19-22]. However, as the high specific lactose uptake rates of the GI strain clearly seemed toxic to the cells, we wanted to check if perhaps IPTG induction was beneficial for this strain. Therefore, we compared data obtained from the cultivation with lactose induction resulting in the highest $\mathrm{q}_{\mathrm{p}}$ to an IPTG-induced cultivation that was conducted at a similar $\mathrm{q}_{\mathrm{s}, \mathrm{glu}}$. For comparability, both inducers were provided in excess. The physiological parameters as well as the specific product formation rates and the cell-lysis data are shown in Figure 5.

\begin{tabular}{|c|c|c|}
\hline & $100 \% \mathrm{q}_{\mathrm{s}, \mathrm{lac}, \max }$ & IPTG \\
\hline$\mu\left[\mathrm{h}^{-1}\right]$ & $0.12 \pm 0.03$ & $0.05 \pm 0.007$ \\
\hline $\mathrm{q}_{\mathrm{s}, \mathrm{glu}}[\mathrm{g} / \mathrm{g} / \mathrm{h}]$ & $0.13 \pm 0.02$ & $0.15 \pm 0.02$ \\
\hline $\mathrm{q}_{\mathrm{s}, \mathrm{lac}, \max }[\mathrm{g} / \mathrm{g} / \mathrm{h}]$ & $0.33 \pm 0.02$ & - \\
\hline $\begin{array}{l}\text { DNA concentration } \\
\text { normalized to biomass } \\
\text { after } 6 \mathrm{~h} \text { of induction } \\
{[\mu \mathrm{g} / \mathrm{g}]}\end{array}$ & $1310 \pm 49$ & $560 \pm 18$ \\
\hline $\begin{array}{l}\text { Leakiness normalized } \\
\text { to homogenate and } \\
\text { biomass after } 6 \mathrm{~h} \text { of } \\
\text { induction }[\%]\end{array}$ & $15.5 \pm 0.5$ & $1.8 \pm 0.04$ \\
\hline
\end{tabular}

(a)

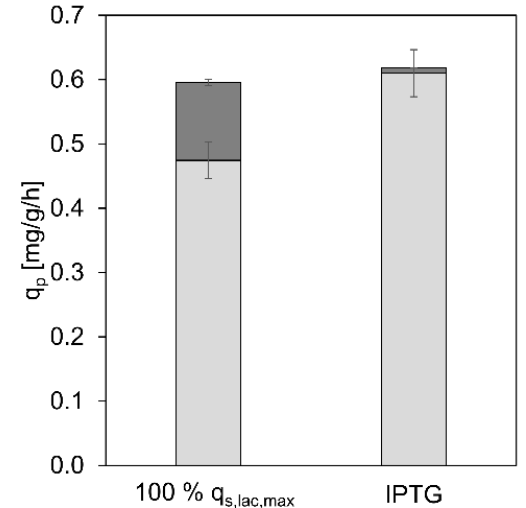

(b)

Figure 5. Physiology, leakiness, lysis, and productivity when inducing FabZ production by lactose or IPTG. (a) Comparison of physiological data as well as cell lysis and leakiness of the lactose induction cultivation at which the highest $\mathrm{q}_{\mathrm{p}}$ was reached and an IPTG-induced cultivation conducted at the same $\mathrm{q}_{\mathrm{s}, \mathrm{glu}}$; (b) specific overall, intracellular (light grey), and extracellular (dark grey) product formation rates of the lactose-induced cultivation at which the highest $q_{p}$ was reached and an IPTG-induced cultivation conducted at the same $\mathrm{q}_{\mathrm{s}, \mathrm{glu}}$.

As shown in Figure 5, the overall $\mathrm{q}_{\mathrm{p}}$ is similar in the lactose and the IPTG-induced process, however, the extracellular product formation is clearly reduced in the IPTG-induced process in comparison to lactose-induced cells. This most likely is a result of less cell lysis and leakiness in the IPTG-induced cultivation as shown in Figure 5a. All of this indicates that for a GI strain, with the GOI 
under control of the T7 promoter, lactose induction does not provide the same advantages which were previously discovered for plasmid-based systems. On the contrary, it seems to slightly reduce overall productivity and clearly diminishes cell viability compared to IPTG induction.

\section{Conclusions}

In this study we investigated the effects of lactose induction on an E. coli BL21 (DE3) expression system with a genome-integrated GOI. Previously, only plasmid-based expression systems had been subject to studies investigating lactose as an inducer for recombinant protein production [23,36,37]. In those studies, beneficial effects on productivity, cell fitness, viability, and soluble product formation had been reported [21,22,38-40].

Within this study we showed, for the first time, that an E. coli BL21 (DE3) expression system with a genome-integrated GOI showed specific maximum lactose uptake rates that were more than double as high compared to pET-plasmid based systems. We demonstrated that this difference is caused by the lack of a plasmid carrying additional copies of lacI and further showed that these unusually high lactose uptake rates of more than $0.4 \mathrm{~g} / \mathrm{g} / \mathrm{h}$ were toxic to the cells leading to increased cell lysis and product loss in the supernatant. Therefore, we conclude that previously discovered benefits of lactose induction are not applicable to strains with genome integrated GOIs under control of the T7 promoter.

Supplementary Materials: The following are available online at http://www.mdpi.com/2306-5354/7/1/8/s1, Table S1: Physiological parameters of cultivations at $\mathrm{q}_{\mathrm{s}, \mathrm{lac} \text {, max }}$ at different $\mathrm{q}_{\mathrm{s}, \mathrm{glu}}$.

Author Contributions: Conceptualization, O.S.; methodology, O.S. and J.H.; software, J.H.; validation, J.H. and R.K.; formal analysis, R.K.; investigation, J.H. and R.K.; resources, J.D.G. and D.R.; writing-original draft preparation, R.K. and J.H.; writing-review and editing, J.H., O.S., J.D.G. and D.R.; visualization, J.H. and R.K.; supervision, O.S. and D.R.; project administration, O.S., J.D.G. and D.R.; funding acquisition, O.S. All authors have read and agreed to the published version of the manuscript.

Funding: This research was funded by Boehringer Ingelheim RCV GmbH and Co KG.

Acknowledgments: The authors are very grateful to Martin Voigtmann and team for evaluation of Fab-expression levels. The authors acknowledge TU Wien Bibliothek for financial support through its Open Access Funding by TU Wien.

Conflicts of Interest: J.D.G. and D.R. were employees of Boehringer Ingelheim RCV GmbH \& Co KG when this study was conducted.

\section{References}

1. Jia, B.; Jeon, C.O. High-throughput recombinant protein expression in Escherichia coli: Current status and future perspectives. Open Biol. 2016, 6, 160196. [CrossRef] [PubMed]

2. Sørensen, H.P.; Mortensen, K.K. Advanced genetic strategies for recombinant protein expression in Escherichia coli. J. Biotechnol. 2005, 115, 113-128. [CrossRef] [PubMed]

3. Rosano, G.L.; Ceccarelli, E.A. Recombinant protein expression in Escherichia coli: Advances and challenges. Front. Microbiol. 2014, 5, 172. [CrossRef] [PubMed]

4. Sezonov, G.; Joseleau-Petit, D.; D'Ari, R. Escherichia coli physiology in Luria-Bertani broth. J. Bacteriol. 2007, 189, 8746-8749. [CrossRef] [PubMed]

5. Daegelen, P.; Studier, F.W.; Lenski, R.E.; Cure, S.; Kim, J.F. Tracing Ancestors and Relatives of Escherichia coli B, and the Derivation of B Strains REL606 and BL21(DE3). J. Mol. Biol. 2009, 394, 634-643. [CrossRef] [PubMed]

6. Fulcrand, G.; Dages, S.; Zh, X.; Chapagain, P.; Gerstman, B.S.; Dunlap, D.; Leng, F. DNA supercoiling, a critical signal regulating the basal expression of the lac operon in Escherichia coli. Sci. Rep. 2016, 6, 19243. [CrossRef]

7. Studier, F.W.; Moffatt, B.A. Use of Bacteriophage-T7 Rna-Polymerase to Direct Selective High-Level Expression of Cloned Genes. J. Mol. Biol. 1986, 189, 113-130. [CrossRef]

8. Studier, F.W. Use of bacteriophage T7 lysozyme to improve an inducible T7 expression system. J. Mol. Biol. 1991, 219, 37-44. [CrossRef]

9. Dubendorff, J.W.; Studier, F.W. Controlling basal expression in an inducible T7 expression system by blocking the target T7 promoter with lac repressor. J. Mol. Biol. 1991, 219, 45-59. [CrossRef] 
10. Popov, M.; Petrov, S.; Nacheva, G.; Ivanov, I.; Reichl, U. Effects of a recombinant gene expression on ColE1-like plasmid segregation in Escherichia coli. BMC Biotechnol. 2011, 11, 18. [CrossRef]

11. Teich, A.; Lin, H.Y.; Andersson, L.; Meyer, S.; Neubauer, P. Amplification of ColE1 related plasmids in recombinant cultures of Escherichia coli after IPTG induction. J. Biotechnol. 1998, 64, 197-210. [CrossRef]

12. Juhas, M.; Ajioka, J.W. Lambda Red recombinase-mediated integration of the high molecular weight DNA into the Escherichia coli chromosome. Microb. Cell Fact. 2016, 15, 172. [CrossRef] [PubMed]

13. Juhas, M.; Ajioka, J.W. Flagellar region 3b supports strong expression of integrated DNA and the highest chromosomal integration efficiency of the Escherichia coli flagellar regions. Microb. Biotechnol. 2015, 8, 726-738. [CrossRef] [PubMed]

14. Striedner, G.; Pfaffenzeller, I.; Markus, L.; Nemecek, S.; Grabherr, R.; Bayer, K. Plasmid-free T7-based Escherichia coli expression systems. Biotechnol. Bioeng. 2010, 105, 786-794.

15. Fink, M.; Vazulka, S.; Egger, E.; Jarmer, J.; Grabherr, R.; Cserjan-Puschmann, M.; Striedner, G. Micro-bioreactor cultivations of Fab producing Escherichia coli reveal genome-integrated systems as suitable for prospective studies on direct Fab expression effects. Biotechnol. J. 2019, 14, e1800637. [CrossRef]

16. St-Pierre, F.; Cui, L.; Priest, D.G.; Endy, D.; Dodd, I.B.; Shearwin, K.E. One-Step Cloning and Chromosomal Integration of DNA. ACS Synth. Biol. 2013, 2, 537-541. [CrossRef]

17. Dvorak, P.; Chrast, L.; Nikel, P.I.; Fedr, R.; Soucek, K.; Sedlackova, M.; Chaloupkova, R.; de Lorenzo, V.; Prokop, Z.; Damborsky, J. Exacerbation of substrate toxicity by IPTG in Escherichia coli BL21(DE3) carrying a synthetic metabolic pathway. Microb. Cell Fact. 2015, 14, 201. [CrossRef]

18. Nausch, H.; Huckauf, J.; Koslowski, R.; Meyer, U.; Broer, I.; Mikschofsky, H. Recombinant production of human interleukin 6 in Escherichia coli. PLoS ONE 2013, 8, e54933. [CrossRef]

19. Gombert, A.K.; Kilikian, B.V. Recombinant gene expression in Escherichia coli cultivation using lactose as inducer. J. Biotechnol. 1998, 60, 47-54. [CrossRef]

20. Wurm, D.J.; Quehenberger, J.; Mildner, J.; Eggenreich, B.; Slouka, C.; Schwaighofer, A.; Wieland, K.; Lendl, B.; Rajamanickam, V.; Herwig, C.; et al. Teaching an old pET new tricks: Tuning of inclusion body formation and properties by a mixed feed system in E. coli. Appl. Microbiol. Biotechnol. 2018, 102, 667-676. [CrossRef]

21. Fruchtl, M.; Sakon, J.; Beitle, R. Expression of a collagen-binding domain fusion protein: Effect of amino acid supplementation, inducer type, and culture conditions. Biotechnol. Prog. 2015, 31, 503-509. [CrossRef] [PubMed]

22. Bashir, H.; Ahmed, N.; Khan, M.A.; Zafar, A.U.; Tahir, S.; Khan, M.I.; Khan, F.; Husnain, T. Simple procedure applying lactose induction and one-step purification for high-yield production of rhCIFN. Biotechnol. Appl. Biochem. 2016, 63, 708-714. [CrossRef] [PubMed]

23. Wurm, D.J.; Hausjell, J.; Ulonska, S.; Herwig, C.; Spadiut, O. Mechanistic platform knowledge of concomitant sugar uptake in Escherichia coli BL21(DE3) strains. Sci. Rep. 2017, 7, 45072. [CrossRef] [PubMed]

24. Wurm, D.J.; Veiter, L.; Ulonska, S.; Eggenreich, B.; Herwig, C.; Spadiut, O. The E. coli pET expression system revisited-mechanistic correlation between glucose and lactose uptake. Appl. Microbiol. Biotechnol. 2016, 100, 8721-8729. [CrossRef] [PubMed]

25. Wurm, D.J.; Marschall, L.; Sagmeister, P.; Herwig, C.; Spadiut, O. Simple monitoring of cell leakiness and viability in Escherichia coli bioprocesses-A case study. Eng. Life Sci. 2017, 17, 598-604. [CrossRef]

26. Sharan, S.K.; Thomason, L.C.; Kuznetsov, S.G.; Court, D.L. Recombineering: A homologous recombination-based method of genetic engineering. Nat. Protoc. 2009, 4, 206-223. [CrossRef]

27. DeLisa, M.P.; Li, J.; Rao, G.; Weigand, W.A.; Bentley, W.E. Monitoring GFP-operon fusion protein expression during high cell density cultivation of Escherichia coli using an on-line optical sensor. Biotechnol. Bioeng. 1999, 65, 54-64. [CrossRef]

28. Janzen, N.H.; Striedner, G.; Jarmer, J.; Voigtmann, M.; Abad, S.; Reinisch, D. Implementation of a Fully Automated Microbial Cultivation Platform for Strain and Process Screening. Biotechnol. J. 2019, 14, e1800625. [CrossRef]

29. Kremling, A.; Bettenbrock, K.; Laube, B.; Jahreis, K.; Lengeler, J.W.; Gilles, E.D. The organization of metabolic reaction networks. III. Application for diauxic growth on glucose and lactose. Metab. Eng. 2001, 3, 362-379. [CrossRef]

30. Kremling, A.; Geiselmann, J.; Ropers, D.; de Jong, H. Understanding carbon catabolite repression in Escherichia coli using quantitative models. Trends Microbiol. 2015, 23, 99-109. [CrossRef] 
31. Loomis, W.F.J.; Magasanik, B. Glucose-lactose diauxie in Escherichia coli. J. Bacteriol. 1967, 93, $1397-1401$. [CrossRef]

32. Dykhuizen, D.; Hartl, D. Transport by the lactose permease of Escherichia coli as the basis of lactose killing. J. Bacteriol. 1978, 135, 876-882. [CrossRef]

33. Wilson, D.M.; Putzrath, R.M.; Wilson, T.H. Inhibition of growth of Escherichia coli by lactose and other galactosides. Biochim. Biophys. Acta 1981, 649, 377-384. [CrossRef]

34. Kopp, J.; Slouka, C.; Ulonska, S.; Kager, J.; Fricke, J.; Spadiut, O.; Herwig, C. Impact of Glycerol as Carbon Source onto Specific Sugar and Inducer Uptake Rates and Inclusion Body Productivity in E. coli BL21(DE3). Bioengineering 2017, 5, 1. [CrossRef] [PubMed]

35. Jeong, H.; Barbe, V.; Lee, C.H.; Vallenet, D.; Yu, D.S.; Choi, S.H.; Couloux, A.; Lee, S.W.; Yoon, S.H.; Cattolico, L.; et al. Genome sequences of Escherichia coli B strains REL606 and BL21(DE3). J. Mol. Biol. 2009, 394, 644-652. [CrossRef] [PubMed]

36. Sina, M.; Farajzadeh, D.; Dastmalchi, S. Effects of Environmental Factors on Soluble Expression of a Humanized Anti-TNF- $\alpha$ scFv Antibody in Escherichia coli. Adv. Pharm. Bull. 2015, 5, 455-461. [CrossRef] [PubMed]

37. Pei, X.-L.; Wang, Q.-Y.; Li, C.-L.; Qiu, X.-F.; Xie, K.-L.; Huang, L.-F.; Wang, A.-M.; Zeng, Z.-W.; Xie, T. Efficient Production of a Thermophilic 2-Deoxyribose-5-Phosphate Aldolase in Glucose-Limited Fed-Batch Cultivations of Escherichia coli by Continuous Lactose Induction Strategy. Appl. Biochem. Biotechnol. 2011, 165, 416-425. [CrossRef]

38. Tian, H.; Tang, L.; Wang, Y.; Wang, X.; Guan, L.; Zhang, J.; Wu, X.; Li, X. Lactose Induction Increases Production of Recombinant Keratinocyte Growth Factor-2 in Escherichia coli. Int. J. Pept. Res. Ther. 2011, 17, 123-129. [CrossRef]

39. Huang, L.; Wang, Q.; Jiang, S.; Zhou, Y.; Zhang, G.; Ma, Y. Improved extracellular expression and high-cell-density fed-batch fermentation of chitosanase from Aspergillus Fumigatus in Escherichia coli. Bioprocess Biosyst. Eng. 2016, 39, 1679-1687. [CrossRef]

40. Kim, S.; Cheung, L.H.; Zhang, W.; Rosenblum, M.G. Improved expression of a soluble single chain antibody fusion protein containing tumor necrosis factor in Escherichia coli. Appl. Microbiol. Biotechnol. 2007, 77, 99-106. [CrossRef] 